УДК 327(437.6+470+571): 620.91+621.039

DOI: $10.24144 / 2218-5348.2019 .1-2(19-20) .111-120$

Купар Діана,

кандидат історичних наук, старший викладач кафедри міжнародних студій та суспільних комунікацій ДВНЗ «Ужсгородський національний університет»

\title{
СЛОВАЦЬКО-РОСІЙСЬКЕ СПІВРОБІТНИЦТВО У СФЕРІ ЯДЕРНОЇ ЕНЕРГЕТИКИ
}

У статті досліджусться економічна та політична складова словачько-російського співробітнищтва у сфері ядерної енергетики у кіниі XX - на початку XXI століття. На сьогоднішній день у Словаччині діють чотири атомні енергоблоки та два будуть введені в експлуатацію у 2020 р. Ключова роль у забезпеченні поставок ядерного палива та технічного обслуговування належсть саме російським компаніям. Це створює значні ризики для Словаччини, яка майже повністю залежна від російських енергоресурсів.

Ключові слова: енергетична стратегія; енергетичний баланс; ядерне паливо; атомна електростаниія; Словацька республіка; Російська Федераиія.

The article deals with the main factors of the Slovak-Russian cooperation in the field of nuclear energy, its dynamics and development prospects. The author analyzes the main energy strategies of both countries and the basic documents in the field of energy policy. Special attention is paid to political aspects of the Slovak-Russian cooperation in the nuclear energy industry. Slovakia has four operational nuclear reactors, two reactors at Mochovce are expected to be operational in 2020. Russian companies have a key role in supplying nuclear fuel to these nuclear power plants and providing all kinds of technical support. At the legislative level, the energy policy of the Slovak Republic is formed within the framework of the objectives of the European Union's energy policy, which envisage a high level of energy security and competitiveness. in practice, Slovakia is only deepening its dependence on the Russian Federation, undermining its own energy security and that of the European Union as a whole. Russia has widely used the practice of using energy as a means of political pressure The Russian government continues to stimulate nuclear reactor export with state funds. Many Slovak politicians also express their positive attitude towards deepening energy cooperation between the countries. Ehis is a clear confirmation of the high degree of Russian influence on the political elite of Central European countries. 
Keywords: energy strategy; energy balance; nuclear fuel; nuclear power plant; The Slovak Republic; Russian Federation.

Ядерна енергетика як джерело чистої безвуглецевої енергії відіграє дедалі вагомішу роль у світовому енергетичному балансі. Зменшення запасів викопного палива, зростання енергетичної залежності країн та наміри Свропейського Союзу щодо скорочення викидів вуглекислого газу на $40 \%$ до 2030 р., з одного боку, підтверджують необхідність розвитку ядерної енергетики в Свропі, проте аварії на Чорнобильській АЕC в Україні й AEC «Фукусіма» в Японії змусили громадськість серйозно замислитися про можливі негативні наслідки використання такого виду енергії.

Для країн Центральної Європи, які характеризуються високим рівнем енергетичної залежності, атомна енергетика може стати ключем для вирішення багатьох проблем. Проте побудова нових реакторів, чи оновлення існуючих, $\epsilon$ дуже тривалим i дорогим проектом. Більшість існуючих реакторів у регіоні були побудовані за радянськими технологіями, і на сьогоднішній день Росія намагається зберегти свої позиції в регіоні. Словацько-російське співробітництво у сфері ядерної енергетики є яскравим прикладом успішної реалізації планів Москви щодо утримання сфер впливу в регіоні.

Метою дослідження $\epsilon$ вивчення словацько-російського співробітництва в ядерній сфері у кінці XX - на початку XXI ст., його економічної та політичної складові.

Під час дослідження проблеми автором були використані документи, які визначають основи здійснення енергетичної політики Словацької Республіки та Російської Федерації, а саме «Енергетична політика Росії на період до 2035 р.»[8], «Стратегія енергетичної безпеки Словацької Республіки» [11], «Закон про енергетику та доповнення деяких законів» [20], «Комплексний національний план 3 питань енергетики та клімату на 20212030 роки»[12]. Нами також було проаналізовано значну кількість матеріалів 3 офіційних сайтів Міністерства економіки Словацької Республіки та Міністерства енергетики Російської Федерації, а також публікації інформаційно-аналітичного характеру української, російської та словацької преси.

Вивченню політичних та економічних відносин Росії і країн Центрально-Східної Європи присвячено низку робіт російських вчених Інституту економіки РАН. Словацько-російські відносини і сфері енергетики висвітлені в таких працях: «Росія та Центрально-Східна Європа: взаємовідносини в 2008-2009 рр.» [5]; «Російський фактор в енергетичній політиці країн Центральної та Південно-Східної Свропи» [4].

Ставши членом Європейського Союзу, Словаччина прийняла європейську енергетичну політику i почала здійснювати реформи 
енергетичного сектору. Енергетична політика Словацької Республіки формується в рамках завдань та цілей енергетичної політики Свропейського Союзу, які передбачають зниження викидів вуглекислого газу, збільшення енергетичної ефективності та ширшого використання відновлюваних джерел енергії. Стратегічна мета енергетичної політики Словаччини базується на трьох основних принципах європейської енергетичної політики, а саме: енергетичній безпеці, конкурентоспроможності, стабільності [13]. Основним документом, який регулює енергетичну політику Словаччини на сучасному етапі, є «Енергетична політика Словацької Республіки» (2014р.). У рамках імплементації третього енергетичного пакету СС 31 липня 2012 р. був прийнятий новий Закон про енергетику та доповнення деяких законів, який спрямований в першу чергу на захист прав споживачів та посилення конкурентного середовища на газовому ринку [20].

У жовтні 2019 р. уряд Словацької Республіки схвалив Комплексний національний план 3 питань енергетики та клімату на 2021-2030 роки, який передбачає зростання частки відновлюваних джерел в енергетичному балансі країни до 19,2 \%, що на 5,2 \% більше, ніж у стартегії до 2020 р. У плані також зазначається, що після введення в експлуатацію недобудованих блоків у Моховце буде проблематично збільшити частку відновлюваних джерел в енергобалансі (в енергетичній стратегії СС до 2030 запланована частка відновлюваних джерел енергії становить 32 \%) [12].

Атомній енергетиці належить провідна роль у забезпеченні Словацької Республіки електроенергією. Частка ядерного пального в енергетичному балансі країни 24 \%. Атомні електростанції Словаччини «Богуніце» та «Моховце» були побудовані за сприяння СРСР та оснащені радянськими реакторами водяного типу. В 1972 р. було завершено будівництво першої в регіоні АЕС «Богуніце - 1», на якій були встановлені два реактори типу ВВЕР-440 за участі підприємств «Атомстройекспорт» та «Шкода». Ця електростанція пропрацювала до 1977 р. Енергоблоки «Богуніце - 2» потужністю 440 Мвт, розроблені підприємством «Атоменергопроєкт» розпочали роботу в 1984 та 1985 рр. Перший та другий енергоблоки АЕС «Моховце» розпочали роботу в 1998 та 1999 рр. Вони також оснащені реакторами типу ВВЕР-440. Будівництво третього та четвертого енергоблоків було призупинене в 1992 р. На сьогоднішній день в Словаччині діють чотири атомні енергоблоки та два знаходилися в процесі будівництва. Власником та оператором АЕС «Богуніце-2» та «Моховце» $\mathrm{\epsilon}$ компанія «Словацькі електростанції» [14].

Після завершення будівництва двох блоків АЕС «Моховце» в 1998 та 2000 pp. і до 2006 p. Словаччина повністю забезпечувала себе електроенергією і навіть була експортером. У зв'язку 3 приєднанням Словаччини до Європейського Союзу уряд взяв на себе зобов'язання достроково закрити енергоблоки 1 та 2 AEC в Ясловське Богуніце. 
Європейський Союз зобов'язався надати фінансову допомогу для цього. Для Словацької Республіки створено Міжнародний фонд підтримки виведення 3 експлуатації AEC «Богуніце», яким керує Європейський банк реконструкції та розвитку [19].

Після закриття першого та другого енергоблоків АЕС «Богуніце» в 2006 та 2008 рр. Словаччина перетворилася на імпортера електроенергії. Так, якщо в 2005 р. виробництво електроенергії становило 31294 Гвт, а споживання становило - 28572 Гвт, то в 2009 р. виробництво електроенергії впало до 26074 Гвт при споживанні - 27386 Гвт [13].

Під час газової кризи в січні 2009 р. Р. Фіцо виступав із заявами про відновлення роботи другого енергоблоку АЕС «Богуніце», оскільки Словаччина не могла забезпечити свою потребу в електроенергії [18]. Прем'єр-міністр неодноразово виступав із заявами про те, що згода попередніх урядів на закриття першого та другого блоків АЕС «Богуніце» була «енергетичною зрадою» Словаччини [15].

Відповідно до Енергетичної стратегії Росії до 2035 р. російська атомна енергетика становить $5 \%$ світового ринку атомної електрогенерації, $15 \%$ світового ринку реакторобудування, $45 \%$ - збагачення урану, $15 \%$ світового ринку конверсії відпрацьованого палива та забезпечує $8 \%$ світового видобутку природного урану. Зовнішній виклик для енергетики Росії, як зазначається в документі, полягає в кардинальному посиленні конкуренції на зовнішніх енергетичних ринках. Посилюється «конкурентна боротьба за утримання та нарощування частки на ключових традиційних $\mathrm{i}$ нових енергетичних ринках» [8]. Однак Росія докладає максимальних зусиль для утримання контролю над Євразійським енергетичним ринком.

Російська компанія «Атомстройекспорт» брала у часть у роботах по модернізації третього та четвертого енергоблоків АЕС «Богуніце». Зокрема в період 32005 по 2008 рр. було проведено заміну апаратури контролю нейтронного потоку на обох енергоблоках, а в період з 2007 по 2008 рp. заміну переривників системи управління та захисту реактора [2].

В лютому 2005 р. уряд Словаччини схвалив продаж найбільшого енергетичного підприємства Словаччини «Словацькі електростанції» італійській енергетичній компанії Енел. Відповідна угода була підписана 17 лютого 2005 р. Енел стала власником $66 \%$ акцій за суму в 850 млн. євро. Однією з основних вимог уряду було не тільки придбання підприємства як єдиного активу, але також залучення значних інвестицій у розширення виробничих потужностей. Р. Фіцо, будучи лідером в той час опозиційної партії «Смер», піддав гострій критиці продаж акцій підприємства «Словацькі електростанції», ставлячи під сумнів готовність італійської компанії до значних капіталовкладень у розвиток словацької енергетики [9]. Участь у приватизаційному тендері взяло також російське акціонерне товариство «ЕЕС Росії», проте, за словами тодішнього міністра економіки П. Руско 
тендерна комісія виявила стурбованість щодо стану енергетичного сектора Росії. Російська сторона в цьому рішенні вбачала винятково політичний контекст [4, с. 226].

У лютому 2007 р. АТ «Словацькі електростанції» оголосило про наміри добудови третього та четвертого блоків АЕС «Моховце» [17]. Відповідно до договору про Євроатом будь-які нові ядерні проекти та інвестиції повинні спочатку узгоджуватися 3 Європейською Комісією. 15 липня 2008 р. Європейська Комісія постановила, що за умов виконання низки рекомендацій інвестори можуть розпочинати роботу по завершенню будівництва двох реакторів АЕС «Моховце» [10].

У 2008 р. російське акціонерне товариство «ТВЕЛ» виграло тендер на постачання російського ядерного палива для словацьких АЕС «Моховце» (1 та 2 блоки) та «Богуніце» (3 та 4 блоки). В тендері бала участь також японо-американська компанія «Вестінгхаус», яка єдина у світі пропонує реальну альтернативу російському пальному для реакторів типу ВВЕР, проте саме Росія прагне закріпити в довгостроковій перспективі статус ексклюзивного постачальника ядерного палива на словацький ринок. 17 листопада 2008 р. були підписані контракти на поставки палива для всіх діючих блоків словацьких АЕС, які періодично поновлювалися протягом наступних років [5, с. 200].

У квітні 2008 р. під час візиту до Братислави прем'єр-міністра РФ В. Зубкова російська сторона запропонувала словацьким колегам долучитися до створення Центру із збагачення урану в Ангарську, що забезпечило б ій гарантовані поставки палива. Попередньо у серпні 2007 р. співголовою Російсько-словацької ділової ради було обрано президента компанії «Атомстройекспорт» С. Шматко [4, с. 232].

У червні 2009 р. офіційно розпочався процес завершення будівництва третього та четвертого енергоблоків АЕС «Моховце» 3 реакторами ВВЕР440. Основним субпідрядником при виготовленні необхідного обладнання ядерного острова другої черги станції за результатами тендера 2008 р. було обрано чеський завод «Шкода-ЯМ» (Skoda-JS), який входить у структуру російської групи ОМЗ. Відповідний контракт на суму більше 517 млн. доларів був підписаний 11 червня 2009 р. На початку переговорного процесу російська сторона сподівалася, що «Шкода-ЯМ» укладе договір генпідряду на проведення будівельно-монтажних робіт вартістю більше 2 млрд. євро. Проте АТ «Словацькі електростанції» прийняло рішення добудовувати енергоблоки самостійно, в результаті чого «Шкода-ЯМ» перетворилася на субпідрядника і підписала набагато менш вигідний контракт, ніж очікувалося [5, с. 201].Строки завершення будівництва неодноразово переносилися і в жовтні 2016 року оцінювалися як - 2018 р. для 3-го енергоблоку і 2019 р. для 4-го енергоблоку. 
17 листопада 2009 р. в Москві в під час другого засідання словацькоросійської робочої групи з атомної енергетики, яке відбулося в рамках діяльності Міжурядової комісії 3 економічного i науково-технічного співробітництва між Словаччиною та Росією, була узгоджена і підписана довгострокова програма словацько-російського співробітництва в галузі атомної енергетики, яка передбачає участь російських підприємств у модернізації діючих блоків словацьких АЕС та подальшого розвитку атомної енергетики в країні [6].

У добудові третього та четвертого енергоблоків АЕС «Моховце» також бере участь ЗАТ «Атомстройекспорт». 11 травня 2010 р. компанія підписала контракт з АТ «Словацькі електростанції» на постачання систем внутрішнього реакторного контролю, вимірювання концентрації бору i підсистеми вимірювання рівня теплоносія в реакторній установці. У кінці червня 2010 р. досягнуто домовленості з АТ «Словацькі електростанції»на постачання системи моніторингу нейтронного шуму всередині реактора i 25 лютого 2011 р. підписано відповідне доповнення до контракту [1].

Росія також прагне до тісної співпраці зі словацькою стороною у плані подальшого розвитку атомної енергетики та участі у високотехнологічних проєктах, пов'язаних із застосуванням ядерних технологій у промисловості та медицині. Російські спеціалісти брали участь у створенні Міжнародного лазерного центру в Братиславі, Центру протоннопроменевої терапії в м. Ружомберок та науково-дослідного підприємства «Циклотронний центр» [3]. Для просування російських атомних технологій у листопаді 2012 р. компанія «Русатом Оверсіз» зареєструвала в Словаччині свій маркетинговий офіс. Продовжується російсько-словацька співпраця по виведенню з експлуатації трьох зупинених 1 та 2 АЕС «Ясловске Богуніце» та $\mathrm{AEC} \ll \mathrm{A} 1 »$.

Ефективна співпраця у сфері енергетики була однією з головних тем переговорів Міжурядової комісії 3 питань економічного та науковотехнічного співробітництва між Словацькою Республікою та Російською Федерацією, яка проходила 16 жовтня 2018 р. у Татранській Ломниці. Словацьку делегацію очолив міністр економіки П. Жига, а російську делегацію - міністр промисловості та торгівлі Д. Мантуров. За словами П. Жиги «хороша економічна співпраця з Росією важлива для нашої країни, а також має вирішальне значення для енергетичної безпеки» [16]. Ця заява $€$ досить незвичною, якщо врахувати задекларований Словаччиною курс на диверсифікацію джерел енергопостачання.

У травні 2019 р. Словаччина відклала запланований запуск третього та четвертого енегроблоків АЕС «Моховце» внаслідок численних протестів 3 боку сусідньої Австрії, пов'язаних 3 побоюваннями щодо безпеки експлуатації нових реакторів [7]. 
5 червня 2019 р. компанія «ТВЕЛ» і словацька компанія «Словацькі електростанції» знову підписали контракти щодо постачання ядерного палива на АЕС Словаччини на 2022-2026 роки з можливістю продовження угоди до 2030 року. Документи були підписані в Москві у присутності прем'єр-міністрів Росії та Словаччини Дмитра Медведєва і Петера Пеллегріні.

Поглиблення словацько-російської співпраці у сфері ядерної енергетики не може не викликати занепокоєння на тлі високої енергетичної залежності Словаччини від російських енергоресурсів. На сьогоднішній день Словаччина імпортує з Росії близько 90 \% енергетичної сировини. Це створює великі ризики для економічного та політичного життя країни, адже Росія розцінює експорт енергоресурсів як важіль політичного впливу та інструмент реалізації власних геополітичних цілей. Така висока залежність від однієї країни-постачальника суперечить принципам енергетичної політики країни, закріпленим на законодавчому рівні. Атомна енергетика займає провідне місце у забезпеченні країни електроенергією, а ключова роль у забезепеченні поставок ядерного палива та технічного обслуговування належить російським компаніям. Вартими уваги $\epsilon$ також численні висловлювання словацьких політиків, які підтверджують високий ступінь російського впливу на політичну еліту країн Центральної Європи.

\section{Список використаних джерел}

1. АЭС «Моховце» URL: http://www.atomstroyexport.ru/ about/projects/current/mohovce/

2. ЗАО «Атомстройэкспорт» URL: http://www.atomstroyexport.ru/ resources/daf709004b06c8d68d8aadfa0721735a/rus.pdf

3. О российско-словацких торгово-экономических отношениях URL: http://rusemb.sk/rus/russia-and-slovakia/spravka/

4. Российский фактор в энергетической политике стран Центральной и Юго-Восточной Европы/ отв. ред. к.г.н. Н.В. Куликова. - М.: ИЭ РАН, 2010. -286 с.

5. Россия и Центрально-Восточная Европа: взаимоотношения в 2008-2009 гг. / отв. ред. И.И.Орлик. - М.: ИЭ РАН, 2010. - 264 с.

6. РФ и Словакия подписали долгосрочную программу сотрудничества в атомной энергетике URL: http://www.atominfo.ru/ news/air8097.htm

7. Словаччина перенесла запуск нових реакторів АЕС «Моховце» через заперечення Австрії. URL: https://ua.112.ua/svit/slovachchyna-pereneslazapusk-novykh-reaktoriv-aes-mokhovtse-cherez-zaperechennia-avstrii490781.html 
8. Энергетическая стратегия России на период до 2035 года URL: http: //ac.gov.ru/files/content/1578/11-02-14-energostrategy-2035-pdf.pdf http: $/ /$ minenergo.gov.ru/activity/energostrategy/index.php?sphrase_id=304721

9. Cabinet seals privatization deal URL: http://spectator.sme.sk/ articles/view/18770/3/

10. EC delivers opinion on nuclear power plant URL: http://spectator.sme.sk/articles/view/32435/3/ec_delivers_opinion_on_nuclear_po wer plant.html

11. Energy Policy of the Slovak Republic 2014. URL: https://www.mhsr.sk/uploads/files/47NgRIPQ.pdf

12. Integrovaný národný energetický a klimatický plán na roky 2021 2030 URL: https://www.mhsr.sk/uploads/files/zsrwR58V.pdf

13. Navrh energetickej politiky Slovenskej republiky. Maj 2013 URL: http://www.mhsr.sk/navrh-novej-energetickej-politiky-sr/140507s

14. Nuclear Power in Slovakia URL: http://www.worldnuclear.org/info/Country-Profiles/Countries-O-S/Slovakia/

15. Nuclear reactor closed despite state grumbling URL: http://spectator.sme.sk/articles/view/26208/2/

16. P. Žiga: Dobrá ekonomická spolupráca s Ruskom je pre Slovensko dôležitá URL: https://www.economy.gov.sk/press/p-ziga-dobra-ekonomickaspolupraca-s-ruskom-je-pre-slovensko-dolezita

17. SE to complete Mochovce nuclear power plant URL: http://spectator.sme.sk/articles/view/26870/10/

18. Slovak government plans to restart nuclear reactor URL: http://spectator.sme.sk/articles/view/34070/3/slovak_government_plans_to_restart nuclear_reactor.html

19. Vyrad'ovanie jadrových elektrární URL: https://www.mhsr.sk/ energetika/jadrova-energetika-v-sr/vyradovanie-jadrovych-elektrarni

20. Zákon z 31. júla 2012 o energetike a o zmene a doplnení niektorých zákonov / URL: http://www.zakonypreludi.sk/zz/2012-251

\section{REFERENCES}

1. AES "Moxovce" [Nuclear power plant "Mochovce"]. (n.d.). atomstroyexport.ru Retrieved from http:/www.atomstroyexport.ru/about/projects/ current/mohovce/[in Russian]

2. ZAO "Atomstrojeksport" [JSC Atomstroyexport]. (n.d.). atomstroyexport.ru Retrieved from http://www.atomstroyexport.ru/ resources/daf709004b06c8d68d8aadfa0721735a/rus.pdf[in Russian]

3. O rossijsko-slovackih torgovo-ekonomicheskih otnosheniyah [Russian-Slovak trade and economic relations]. (n.d.). rusemb.sk Retrieved from http://rusemb.sk/rus/russia-and-slovakia/spravka/[in Russian] 
4. Kulikova,N.V. (Eds.). (2010) Rossijskij faktor $v$ energeticheskoj politike stran Central'noj i Yugo-Vostochnoj Evropy[The Russian factor in the energy policy of the countries of Central and Southeastern Europe] Moskva: IE RAN[in Russian]

5. Orlik, I.I. (Eds.). (2010) Rossiya i Central'no-Vostochnaya Evropa: vzaimootnosheniya v 2008-2009 gg. [Russia and Central-Eastern Europe: Relations in 2008-2009] Moskva: IE RAN[in Russian]

6. RF i Slovakiya podpisali dolgosrochnuyu programmu sotrudnichestva $\mathrm{v}$ atomnoj energetike [Russia and Slovakia signed long-term cooperation program in nuclear energy]. (n.d.). atominfo.ru Retrieved from http://www.atominfo.ru /news/air8097.htm[in Russian]

7. Slovachchyna perenesla zapusk novykh reaktoriv AES "Mokhovtse" cherez zaperechennia [Slovakia has delayed the launch of new Mokhovce reactors due to Austria's objections]. (n.d.). ua.112.ua Retrieved from https://ua.112.ua/svit/slovachchyna-perenesla-zapusk-novykh-reaktoriv-aesmokhovtse-cherez-zaperechennia-avstrii-490781.html[in Ukrainian]

8. Energeticheskaya strategiya Rossii na period do 2035 goda [Energy Strategy of the Russian Federation until 2035 ]. (n.d.). ac.gov.ru Retrieved from http://ac.gov.ru/files/content/1578/11-02-14-energostrategy-2035-

pdf.pdfhttp://minenergo.gov.ru/activity/energostrategy/index.php?sphrase_id=3047 21 [in Russian]

9. Cabinet seals privatization deal (n.d.). spectator.sme.sk Retrieved from http://spectator.sme.sk/articles/view/18770/3/ [in English]

10. EC delivers opinion on nuclear power plant (n.d.). spectator.sme.sk Retrieved from http://spectator.sme.sk/articles/view/32435/3/ ec_delivers opinion_on_nuclear_power_plant.html [in English]

11. Energy Policy of the Slovak Republic 2014(n.d.). mhsr.sk Retrieved from https://www.mhsr.sk/uploads/files/47NgRIPQ.pdf [in English]

12. Navrh energetickej politiky Slovenskej republiky. Maj 2013 [Draft Energy Policy of the Slovak Republic. May 2013]. (n.d.). mhsr.sk Retrieved from http://www.mhsr.sk/navrh-novej-energetickej-politiky-sr/140507s [in Slovak]

13. Integrovaný národný energetický a klimatický plán na roky $2021-$ 2030 [Integrated National Energy and Climate Plan for 2021-2030] (n.d.). mhsr.sk Retrieved fromhttps://www.mhsr.sk/uploads/files/zsrwR58V.pdf[in Slovak]

14. Nuclear Power in Slovakia(n.d.). world-nuclear.org Retrieved from http://www.world-nuclear.org/info/Country-Profiles/Countries-O-S/Slovakia/ [in English]

15. Nuclear reactor closed despite state grumbling (n.d.). spectator.sme.sk Retrieved from http://spectator.sme.sk/articles/view/26208/2/ [in English]

16. P. Žiga: Dobrá ekonomická spolupráca s Ruskom je pre Slovensko dôležitá [P. Žiga: Good economic cooperation with Russia is important for Slovakia]. (n.d.). economy.gov.sk Retrieved from https://www.economy.gov.sk/ 
press/p-ziga-dobra-ekonomicka-spolupraca-s-ruskom-je-pre-slovensko-dolezita [in Slovak]

17. SE to complete Mochovce nuclear power plant (n.d.). spectator.sme.sk Retrieved from http://spectator.sme.sk/articles/view/26870/10/ [in English]

18. Slovak government plans to restart nuclear reactor (n.d.). spectator.sme.sk Retrieved from http://spectator.sme.sk/articles/view /34070/3/slovak_government_plans_to_restart_nuclear_reactor.html [in English]

19. Vyrad'ovanie jadrových elektrární [Decommissioning of nuclear power plants]. (n.d.). mhsr.sk Retrieved from https://www.mhsr.sk/energetika/ jadrova-energetika-v-sr/vyradovanie-jadrovych-elektrarni [in Slovak]

20. Zákon z 31. júla 2012 o energetike a o zmene a doplnení niektorých zákonov [Act of 31 July 2012 on energy and amending certain laws]. (n.d.).zakonypreludi.sk Retrieved from http://www.zakonypreludi.sk/zz/2012-251 [in Slovak] 